Vitalii Tolubyak

ORCID ID: 0000-0002-8892-2338

Ternopil National Economic University, Ukraine

\title{
Larysa Mosora
}

ORCID ID: 0000-0003-4341-1937

Ivano-Frankivsk National Technical University

of Oil and Gas, Ukraine

\section{Halyna Kis}

ORCID ID: 0000-0003-1009-7021

Ivano-Frankivsk National Technical University

of Oil and Gas, Ukraine

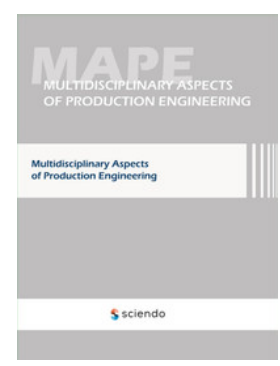

Roman Petryshyn

ORCID ID: 0000-0003-0462-282X

Vasyl Stefanyk Precarpathian National University, Ukraine

\section{INTRODUCTION}

In the context of the globalization of the world economy, the international movement of population becomes the main mechanism for the formation of the international labor market, a connecting link through which countries with a surplus of labor force enter the orbit of global socio-economic processes and join international financial markets. In this case, a rhetorical question arises on what countries should do if they do not have a surplus of labor, but they are also characterized by emigration. That is, in fact, they become so-called donors of labor, often receiving no effect from it, in particular in the sphere of production. In the world the number of migrants has reached an approximate mark of 272 million people in 2019 , which is $51,000,000$ more than in 2010 . UN experts note that migrants currently make up $3.5 \%$ of the world's population (in $2000-2.8 \%$ ). Europe holds the lead as a destination for migrants (82 million people), North America (59 million) and Western Asia (49 million) (Ukrinform site, 2019). Despite the spread of Covid-19 in the world, which somewhat slowed down migration processes, at the end of 2020 the migration rate of population reached 281 million compared to 173 million in 2000 and 221 million in 2010. In fact, over the past century, the number of migrants has increased by 248 million, indicating a rapid growth rate. International migration is gaining momentum today. The reasons for this are economic, political, environmental problems and the like. At the same time, there is also growing forced migration caused by military operations in certain countries and regions of the world. 
International migration is a derivative of the socio-economic aspects that help to overcome the population's poverty. Migration as a social phenomenon plays a significant role in the modernization of the economy, state and society. On the one hand, it is a way of innovative organization of people's life and a factor of progress, on the other hand, it is a historical challenge on the way of preserving the identity of nations and nationalities (Sadova U.Ya., 2018).

Thus, modern migration implements the function of accelerating human development because of the expansion of the individual worldview; it affects the socio-psychological characteristics of the individual, activates the internal resources of a person for social activity. Migration performs redistributive functions, since it is reflected in the dynamics and nature of the course of demographic processes, in the expansion or, conversely, its narrowing due to the change in the sex and age structure of the inhabitants of the territory, in the accumulation of the labor force resource. In its turn, the process of labor migration affects the redistribution of industry types that develop in different countries. That is, in fact, the development of a particular type of industry in a particular country depends not only on natural resources or climate conditions, but also on the availability of appropriate labor resources that can be involved. We conclude that population migration can affect the type of industry that will develop in a particular region of the state and its scale.

Migration is also entrusted with a selective function - not all categories of the population are inclined to it equally. This means that migration contains the potential for qualitative changes in the composition and structure of the economically active (and inactive) population.

The principal feature of modern migration is that it is a phenomenon that is institutionalized, it develops from a traditional social movement into a structured social organism (diaspora, a network of public organizations of labor migrants, infrastructure of the migration services market, etc.), and with this - into a subject and a tool for regulating human economic activity. Despite all the risks and negatives, labor migration is always one of the chances of a person's freedom of choice (Scientific publication, 2019).

In the age of global mobility, labor migrants, diasporas and international communities play an increasingly important role in the development of their countries of origin. Such communities have connections that converge borders, as well as knowledge and resources that are important and necessary for their countries of origin. There is a growing awareness today that these resources can be better used for the humanitarian, intellectual, economic, social and cultural development of their countries of origin. The potential of migration for the development is closely linked to remittances, savings and investment intentions of labor migrants. However, the question of how the human, social and financial capital of labor migrants can be better used for their counties of origin becomes more and more urgent. What can authorities at the national, regional and local levels do to increase the volume and positive impact of money transfers of labor migrants on the future development of the donor country? 
What measures should national governments, the private sector and migrant communities take to create conditions for the productive use of these transfers and increase their positive impact on migrant workers themselves, their households and the economy of the country of origin?

\section{METODOLOGY OF RESEARCH}

Considering the migration relations between Ukraine and Poland, or other countries of the world, tendencies are clearly traced in which Ukraine is a donor, and other countries usually become recipients of labor from Ukraine. But does Ukraine lose something, and does Poland or other recipient countries gain any benefits?

Among scientists (Gotovtseva L.G., Ryazantsev A.P., Khrustalev E.Yu. 2012; Humeniuk Yu.P., 2010) there is a widespread negative assessment of the migration process, which is based on the fact that labor migration reduces the human resources of donor countries. However, this approach is inconsistent with the economic realities of labor donor countries and their national labor markets, especially when it comes to temporary labor migration. It should be noted that unemployment is one of the most important incentives for migration. Therefore, the export of the share of labor to other countries will significantly affect the supply of the national economy with labor and will not cause its deficit. Having analyzed the share of labor migrants in the total population and the unemployment rate according to the ILO methodology for countries where the share of the exported labor force is the largest V.I. Moisei (Moisei V.I., 2015) notes that all countries, where a high proportion of labor migrants may indicate a threat of labor shortages, have a high level of unemployment. Therefore, in such a situation, it is not entirely correct to believe that labor migration poses a threat to the provision of the country's economy with labor. On the contrary, it is logical to assume that in this case the outflow of labor, which is surplus in the national labor market, has a positive effect on the economies of donor countries, since it frees the state from the need for social security of citizens who are unemployed.

Another important aspect is not just the loss of labor, but the loss of highly skilled workers and young workers - graduates of higher education institutions for donor countries. However, it is impossible to estimate these losses due to the lack of relevant statistics. This can only be a guess. The effect of the loss of highly qualified labor force can be estimated through the state's expenditures on training specialists. State funding of education is considered a tool for economic development even in highly developed countries. Therefore, the migration of citizens with higher education to other countries is often viewed as a decrease in the return on public investment in education.

International migration of highly qualified personnel is one of the types of international migration and is called intellectual migration, or "brain drain". "Brain drain" is a process in which scientists, specialists and skilled workers emigrate 
from a country or region for economic, less often political, religious or other reasons.

The phenomenon of intellectual migration is inherent in almost all countries and especially those in which the demand for specialists with higher education is much less than their supply. The labor market is unable to provide highly qualified specialists with jobs, since the development of the country's economy does not provide adequate employment for specialists with higher education. In this case, countries become so-called intellectual donors, since a significant part of their highly educated citizens migrate, as a rule, to economically developed countries.

The migration of highly qualified labor force causes certain negative effects to the economies of countries - labor donors. However, at the same time, it is necessary that citizens with higher education could find employment in their homeland. If they add to the number of unemployed, then their migration to other countries cannot be regarded as a negative effect from an economic point of view. After all, if there are no free places in the economy for such workers, then there is a discrepancy between the state policy on economic development and the development of education, and if such citizens remain in the country, then they will not contribute to economic development, will not participate in the development of different types of industry, but on the contrary, the state will be forced to spend additional funds for their maintenance (making social payments). That is, the state is relieved of its surplus labor force, which does not work anywhere and which also needs to be maintained. Thus, the funds spent at the maintenance of this labor force are more appropriate to invest in the development of any type of industry.

At the same time, if we consider the "brain drain" from the point of view of temporary migration, then this phenomenon also has positive consequences. For example, if a population travels abroad to get a relevant higher education, a second higher education, advanced training or internship, for temporary work, and then returns to the country of origin with new knowledge, this, on the contrary, contributes to the development of various types of industry, improves socio-economic indicators. In fact, in this case, the donor country does not spend money on educating citizens, but can have good dividends, provided that such labor resources return to their country of origin.

It is educational migration that can positively influence the development of industry in the donor country. An example of educational migration is the possibility of obtaining double diplomas in universities of two countries; studying for a Bachelor's or Master's degree; taking advanced training in international organizations (Mosora L., Tolubyak V., Romanyshyn L., Mosora Yu., 2020). Further training, obtaining international certificates with the subsequent return of labor resources in their countries of origin contributes to the dissemination and implementation of the latest foreign production technologies. An example is the advanced training and certification of oil and gas workers in the international 
organization IWCF (Kis S., Mosora L., Mosora Yu., Yatsiuk O., Malynovska G., Pobihun S., 2020).

In the competition for superiority in attracting the intelligence as the carrier and generator of modern scientific knowledge and high technologies, the USA is the leader. Since the mid-1970s and by the beginning of the XXI century the country has attracted 250 thousand highly qualified specialists, and more than $18 \%$ of the employed specialists in the field of information technology in the United States are foreigners. In the last decade, due to the rapid economic development, the migration of highly qualified specialists to the Republic of Korea, Singapore, Thailand, Malaysia, Indonesia, Hong Kong, and China has increased. In Ukraine, as in some other neighbor countries, there is a high level of education, especially in the technical, physical and mathematical direction. Ukraine has significant potential in innovative industries; in particular in the field of IT, therefore it becomes a donor of specialists in these specialties (Yerfan Ye. A., 2018).

Another important aspect is the impact of international migration on the economy of the donor country through the receipt of remittances from labor migrants from other countries, which they send to their families and relatives in their country of origin. The flows of remittances from international labor migrants are constantly growing, which indicates an increase in their influence on the economies of donor countries (Yerfan Ye. A., 2018).

Migrant remittances play an important role in foreign exchange earnings for many countries, creating additional opportunities for consumer and investment demand. Indeed, a significant number of migrant families have low incomes or even live below the poverty line. Accordingly, such households do not have access to credits, are very limited in purchasing consumer goods and are unable to invest. Labor migrants provide their families with the necessary funds, which are used by their families in their homeland not only to meet basic needs, but also to invest in construction, training, starting their own business, and the like. Therefore, migrant remittances, compensating for the limited access to financial resources of a significant number of households in the labor donor country, have a positive effect on the dynamics of private investment, and, consequently, on its business activity.

Large-scale flows of remittances from migrants support their households at home. The monthly amounts of remittances from international migrants to their countries of origin are growing every year, and the vast majority of them are sent to countries with low and middle incomes. In 2020, the volume of international remittances amounted to 445 million US dollars, which, according to World Bank experts, is $19.6 \%$ less than expected in connection with the COVID-19 pandemic (site, 2020). Financial flows of international migrants are a powerful source of external revenues to developing countries (more than $30 \%$ of all external receipts). In addition, such flows are resistant to the impact of crisis phenomena and grow even in crisis conditions. 
Thus, the international migration of highly skilled workers leads to a direct negative external effect in the economies of labor donor countries associated with the loss of part of public investment in education. However, such losses are less than the remittances of migrants to these countries. At the same time, in conditions of high unemployment, the negative impact of labor migration on human resources does not appear, since these migrants themselves are mainly not in demand in the national economy of the country of origin.

As we have already noted, Ukraine often acts as a labor donor for many countries, including Poland. Ukrainian migration has long become a unique national phenomenon of the 21st century. The International Organization for Migration (IOM) constantly carries out activities to raise awareness of ministries and departments responsible for migration policy, representatives of the private sector and civil society on the link between migration and development, as well as on how to effectively use this link in the Ukrainian context. IOM has implemented a large-scale comprehensive study of money transfers of labor migrants to Ukraine in order to inform about the significant impact of Ukrainian labor migrants on the economy of Ukraine, on the development of various types of industry.

Much attention is paid to the study of this issue by the International Labor Organization (ILO) and the State Statistics Service of Ukraine. According to their information, since 2012 labor force migrates from Ukraine to the following main countries: Poland, Italy, Russia, Czech Republic, Spain. The list of countries accepting workers from Ukraine does not change, only the percentage of migrants has changed.

The main spheres in which Ukrainians work in other countries are: construction (over 45\%), households (almost 20\%), agriculture (almost 15\%), trade, transport, hotel business $-2-4 \%$. Most migrants from Ukraine, despite their age, level of education and experience acquired at home, perform unskilled work abroad. The most popular professions are builders (various specializations), pickers of seasonal berries and fruits, cleaners, caretakers for the elderly, less often - drivers (taxis, trucks), cashiers in salesrooms, salespeople.

The flow of Ukrainian labor migration abroad is not decreasing. This trend is clearly observed by sociologists, and the provision of a visa-free regime has only stimulated even more of our fellow citizens to leave the territory of Ukraine in search of better earnings. The authorities have repeatedly set the goal of reducing the flow of labor migration and returning part of Ukrainians back home. Of course, this can be done only by improving the business climate and creating more favorable conditions not only for investors, but also for every ordinary citizen.

In Ukraine, the migration situation has become a significant factor influencing socio-economic development and the state of national, economic and social security. Migration and security are interrelated, because security issues and measures of states affect the processes of internal and external population movement, and the consequences of migration for security determine the impact 
on such spheres of national security as: military, political, economic, social, environmental, legal and socio-cultural.

Large-scale population movements have a significant impact on the Ukrainian economy, bringing both benefits and expenditures. In particular, remittances improve well-being of migrant families and stimulate domestic demand; their stable inflow plays a countercyclical role in the current economic crisis and is one of the main sources of foreign exchange earnings for the country. On the other hand, emigration reduces the supply of labor in the Ukrainian labor market, and, consequently, the potential GDP, and if its use in the destination country is less than its potential, this also leads to a loss of qualifications. Therefore, the policy of using positive results of labor emigration and minimizing its shortcomings is very relevant for Ukraine (Pienkowski Je., 2021).

According to the National Bank of Ukraine, the inflow of remittances to Ukraine is significant. Since 2015, it has steadily increased and in 2019 reached 11.9 billion US dollars, which is equivalent to $7.7 \%$ of GDP. Preliminary data for 2020 show that, despite the economic crisis, remittances of labor migrants amounted to 12.1 billion US dollars (Fig. 1) (Pienkowski Je., 2021). The stability of remittances can be explained by the desire of migrants to compensate their households their absence. Studies have shown that migrants tend to increase their remittances when their countries of origin experience difficult economic conditions in order to compensate for the lost income.

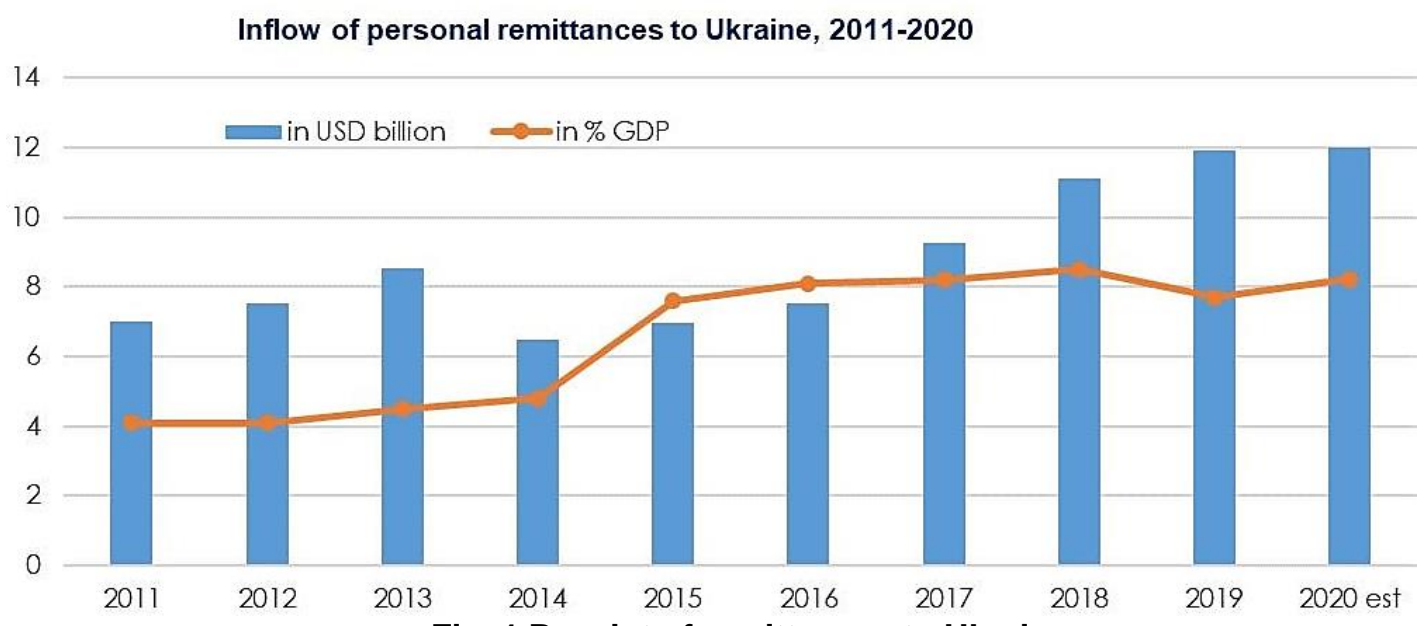

Source: (Pienkowski Je., 2021)

Internationally, Ukraine is the tenth largest recipient of remittances in absolute terms among low- and middle-income countries, and second, after Egypt, among the EU's neighbors. As a share of GDP, remittances to Ukraine are similar to countries such as Armenia and Jordan, but significantly lower than in Lebanon, Moldova and Palestine (Pienkowski Je., 2021).

The most obvious economic consequence of the inflow of remittances is their contribution to improving the well-being of migrant families. Often, such transfers become the basis for starting a new business; they can be investments in a 
certain type of industry. It is estimated that remittances increase household income by about $12 \%$. IOM research shows that about half of remittances to Ukraine are spent on consumption, while the other half is spent on savings, real estate acquisition and renovation, and a small amount is invested. Ukrainian households spend, as a rule, about two-thirds of their expenses on the consumption of domestic goods and services, directly stimulating domestic production. Assuming the same distribution of spending caused by remittances, it can be suggested that consumer demand from remittances directly increases GDP by about 3\%. And this estimate does not include the multiplier effect of consumption as well as the effect of private investment financed by remittances. Therefore, remittances play an important countercyclical role in the current economic crisis in Ukraine.

The impact of remittances and emigration on public finances in Ukraine is ambiguous: remittance receipts lead to an increase in receipts from VAT, excise taxes and customs receipts for goods and services paid for from money transfers. On the other hand, emigrants do not pay labor taxes and social security contributions in Ukraine, while their education was funded by the state. However, in recent years, when Ukraine has experienced significant difficulties, it is clear that remittances have made an important countercyclical contribution, especially due to their impact on budgetary consumption revenues.

Remittances are one of the largest sources of foreign exchange earnings in Ukraine. The average inflow of remittances to Ukraine since 2011 was more than twice as high as foreign direct investment, more than four times for portfolio capital inflows, and more than eight times as high as official development assistance. If the inflow of direct and foreign portfolio investment was very volatile and decreased sharply in 2014-2015 and in 2020, after the corona crisis, the remittances of migrants remained an extremely stable source of currency receipts to Ukraine.

The growing inflow of remittances from labor migrants in general has a noticeable positive effect on the current account of Ukraine and is an essential element that balances out trade and the shortage of investment income. This contributes to the greater stability of Ukraine's balance of payments in recent years, along with other factors such as fiscal regulation, balanced monetary policy, structural reforms, as well as important official macro-financial assistance and other financial support provided to Ukraine, including by the European Union.

Today the question is relevant: will Ukrainian labor migration continue in its current form? Despite the fact that the real wages in Ukraine are growing, the difference in wages with the main areas of labor migration in the EU is so great that it will motivate people to work and earn money abroad. Moreover, the existence of a large and growing Ukrainian diaspora encourages other family members and friends to emigrate, providing information and logistics support in destination countries. And the linguistic and geographical proximity will continue 
to increase the attractiveness of such countries as Poland, Czech Republic, Hungary and others.

Labor migration researches highlight the benefits of engaging with the diaspora and encouraging migrants, especially skilled ones, to invest in their countries and return to them. Benefits include the return of knowledge and skills, the diffusion of technological and managerial knowledge, and the emergence of modern small and medium-sized enterprises. Repatriates can also bring significant savings: according to an IOM survey, the annual savings accumulated by the average Ukrainian long-term migrant abroad is more than twice as much as the annual remittances sent by that person. Some countries have managed to return migrants and attract the diaspora to the development of high-tech industries (India, Israel). Moldova's PARE 1+1 program, which is supported by the EU, has subsidized the creation of new small and mediumsized enterprises by migrants who return to Moldova.

Having returned to their homeland, emigrants bring with them significant material values and work qualifications, managerial experience, which they then use in their country. So, reverse flows, that is, the return of emigrants home from work abroad, over time changes the ratio of benefits and losses in the donor's country.

Considering the number of Ukrainians and the dynamics of migration growth, including to Poland, Ukraine faces the task of shaping a policy that will allow using the potential of Ukrainians working abroad and strengthening ties with them. It is also important to promote the legalization of the migration flow and reduce the risks faced by migrant workers. In case of an appropriate policy, one can expect that these population groups will be most useful both for Ukraine and for other countries as migrants and re-emigrants.

As for the recipient countries, they also face many risks, accepting migrants from other countries. It is impossible to speak unequivocally about the benefits that they receive from population migration. By accepting a certain number of labor migrants, the economy of each recipient country of the labor force is affected by this complex and multifaceted phenomenon. Most often, the economic impact of international labor migration is considered in the context of the national employment market. There are two opposing positions regarding this influence. The first one is that international migration is considered as a factor that creates stress on the national labor market, leading to an increase in the share of unemployed among the local population. The second one assumes that the inflow of labor will help to eliminate the shortage of workers in sectors that are not prestigious among the local population. Public attitude to international labor migration depends on the availability of jobs and the level of unemployment (Rodriguez R.E., 2001).

According to the contribution of international labor migration to the provision of national economies with labor force, all developed countries can be divided into two groups. The first group includes countries where the role of international migration in the growth of the labor force is significant, but not decisive. This 
group includes the USA, the Netherlands, France, Hungary and Germany. In these countries, the contribution of international migration to labor force growth is less than $50 \%$. The second group of countries is more numerous. In the countries of this group, international migration is the main factor in the growth of the personnel potential of the national economy. Thus, in Luxembourg, the contribution of international labor migration to the growth of the labor force exceeds $90 \%$, in Switzerland - 80\%, in the UK - 70\%. And in the Czech Republic, Finland, Italy and Denmark, the growth of the labor force is provided precisely by foreign labor immigrants. Poland, which has received a large number of labor migrants from Ukraine in recent years, should also be included in this group. In this case, Poland acts as a recipient country for the Ukrainians. The COVID-19 pandemic has seriously impacted the global economy, but the implications for each country are different. While some are calculating losses, others are preparing for rapid growth. In particular, Poland, according to some forecasts, may enter the twenty largest economies in the world already in 2030. For this, the country has conditions, including the skillful use of labor from neighboring, less wealthy countries, including Ukraine, as well as the ease of starting and running business, including for foreigners. That is why many Ukrainians leave for Poland and start their own business.

If a few years ago, mostly citizens of the EU countries started their business in Poland, now there is more and more Ukrainians among the foreign owners of companies. So, at the end of March, the Polish Rzeczpospolita daily, referring to the study by the Gremi Personal employment agency, reported that in February 2021, almost four out of five immigrants from Ukraine had plans or were going to start their business in Poland. This means that since last year the number of Ukrainians who want to start their own business in Poland has grown by a third (Ukrinform, site 2021).

According to various sources, up to one and a half million Ukrainian citizens work in Poland today. For example, Selectivv DMP - the Polish marketing company investigated that there were $1,250,000$ citizens who had installed Russian-language or Ukrainian-language applications on their smartphones in Poland. This, according to the researchers, indirectly indicates the number of Ukrainian migrants, of which $56 \%$ are men (Ukrinform, site 2021). And this is a big problem, because the Ukrainian labor market is sorely lacking able-bodied men.

It is often believed that emigrant workers are people who are mature enough, who did not find themselves in their native land, and they go to temporary work in order to earn certain capital, solve their own problems (teaching children, purchasing housing, etc.), and return home with it. In fact, the migration model has changed radically. Now among Ukrainian labor migrants in Poland, 38\% are young people aged 21-30 years and 29\% - under the age of 40 . This is facilitated by the provision of the law that young people under 26 years old with an annual income of 85 thousand PLN per year are exempt from taxes on personal income (Ukrinform, site 2021). 
In addition to the fact that Ukrainian labor migrants in Poland have become "younger", they have also changed their behavior. Polish marketers estimated that $12 \%$ of Ukrainian women in Poland used a family planning app last year, double the number in 2018. Also, the Ukrainian Embassy in Poland said that in 2019 they issued almost 3,000 certificates of birth of Ukrainian citizens in Poland. Moreover, in 2018, there were born 1961 Ukrainians in Poland. According to local researchers, in 2019, Ukrainians spent a total of $\$ 2$ billion in Poland, and the year before this amount was $\$ 1$ billion, although the number of migrants has not increased so much (Ukrinform, site 2021).

Polish business is trying not to miss its chance. Ukrainians are not only a labor force for it, but also a separate target group for the sale of goods and services. Banks, mobile operators, postal companies, insurance agencies and the like have already received offers for potential clients in Ukrainian.

That is, it is correct to state that there is not a direct influence of international labor migration on the growth of unemployment in recipient countries, but the stimulation of certain groups of the local population to obtain the status of unemployed and social assistance, rather than work in a low-profile job. This effect belongs to the negative, but it is only partially associated with international migration. In case of its absence, certain groups of the local labor force still do not fill vacancies in non-prestigious jobs and give preference to receiving social assistance from the state.

So, the overall impact of international migration on recipient countries is largely determined by the share of illegal migration and policies regarding the acceptance of foreign labor. An important point is the availability of methods and mechanisms for identifying labor shortages in individual sectors, as well as determining how the existing deficit can be met by foreign labor and how it should be delivered to the desired employment sector or region. Otherwise, there will be an increase in unemployment among local workers with persistent labor shortages in certain sectors.

International migration makes a great contribution to the growth of the labor force of the recipient countries, among which many countries have demographic problems. Given the demographic deficit, employment-based immigration is becoming increasingly important in the politics of European countries. The decision on whether to grant migrants a residence permit partially depends on whether the host country has an adoption policy or whether it supports permanent labor migration. Traditional immigration countries such as Australia, Canada and the United States have determined that a proportion of permanent immigration is needed to ensure economic growth and provide basic social security guarantees, and they are implementing appropriate migration policies.

\section{RESULTS OF RESEARCH}

Thus, we can talk about the ambiguous impact of migration on donor and recipient countries. Despite the fact that migration can have a threatening scale and cause unpredictable consequences, if it nevertheless becomes 
manageable, it can often contribute to the improvement of the social and economic situation of the state, the development of various types of industry. This is possible in the following cases: firstly, when the labor force, when leaving the country, is unemployed, that is, does not work anywhere for a long period of time; secondly, when it comes to temporary migration, in which labor resources travel abroad to study, improve their qualifications and return to their homeland with new knowledge and experience.

\section{CONCLUSION}

The task for the countries is to maintain a balance of their interests in the process of optimizing migration policy and migration processes, so that they do not harm countries, but, on the contrary, contribute to the development of various types of industry. It is appropriate to develop effective measures for state and regional authorities to stabilize the migration situation. This will enable to regard migration not only as a loss, but as an achievement to ensure the socioeconomic, political and innovative development of the state.

The main directions of regulating migration processes, so that they contribute to the development of the state and various types of industry at the present stage, should be the activation of migration reserves to mitigate depopulation, regulation of labor migration, countering human trafficking, and expanding proposals for investment of migration funds. An active migration policy is the only way to prevent an excessive decrease in the total population, and especially in some regions. The regulation of labor migration should be based on a differentiated approach and should be aimed at the gradual return of those who can be returned and setting cultural relations with those groups of the population who have decided to stay abroad forever.

\section{REFERENCES}

Gotovtseva, L. G., Ryazantsev, A. P. and Khrustalev, E.Yu. (2012). Financial and economic characteristics and trends of interstate labor migration. Problems of forecasting, Volume 4, pp. 80-85.

Humeniuk, Yu. P. (2010). International market of unique labor force: prospects of migrants. Bulletin of the Lviv Polytechnic National University. Volume 691, pp. 321-327.

Kis S., Mosora L. and others. (2020). Personnel certification as a necessary condition for enterprise'staff development. Management Systems in Production Engineering. Volume 2. pp. 121-126.

Labor migration: a challenge for business, opportunities for staff. [online]. 2019. Available at: https://zn.ua/ukr/business/trudova-migraciya-viklik-dlya-biznesumozhlivosti-dlya-personalu-307024_html [Accessed 05 May. 2021].

Moisei, V. I. (2015). External economic effects of labor force migration. Dissertation for the Candidate of Economic Sciences Degree. Specialty 08.00.02 - World Economy and International Economic Relations, $235 \mathrm{p}$.

Mosora L., Tolubyak V. and others. (2020). Migration Factor of Stimuling the Development of the Production Industry in Ukraine and Poland. Multidisciplinary Aspects of Production Engineering. pp. 732-744. 
Pienkowski, Je. (2021). The impact of labor migration on the Ukrainian economy. [online]. Available at: https://voxukraine.org/vpliv-trudovoyi-migratsiyi-naukrayinsku-ekonomiku/ [Accessed 07 May. 2021].

Rodriguez, R. E. and Tiongson, R. E. (2001). Temporary Migration Overseas and Household Labor Supply: Evidence from Urban Philippines. International Migration Review. № 35(3). pp. 709-725.

Sadova, U.Ya. and others. (2018). Migration phenomena and processes: concepts, methods, facts in: Referencebook, Dolishniy Institute of Regional Research of NAS of Ukraine, 2nd ed., Lviv, Ukrainian, $226 \mathrm{p}$.

Ukrainian migration in the context of global and national challenges of the XXI century. Scientific publication. 2019. 110 p.

Ukrinform. (2021). The Polish leadership welcomes Ukrainian migrant workers. And what about ours? [online]. Available at: https://www.ukrinform.ua/rubricsociety/2884960-ukrainciv-laskavo-prosat-do-polsi.html

Ukrinform. (2019). The number of migrants in the world has exceeded 270 million. [online]. Available at: https://www.ukrinform.ua/rubric-world/2782330-kilkistmigrantiv-u-sviti-perevisila-270-miljoniv.html

Yerfan Ye. A. (2018). Features of international migration of highly skilled workers. Available at: http://www.visnyk-econom.uzhnu.uz.ua/archive/18_2_2018ua/4.pdf

\begin{abstract}
The article examines the influence of migration processes on the formation and development of production capacities of countries. The main functions that perform population migration are indicated. Reasonably, the process of labor migration affects the redistribution of industry types that develop in different countries. The impact of international labor migration on the economies of donor and recipient countries is determined. It has been proven that labor migration has different effects on donor and recipient countries. Researched the question of how the human, social and financial capital of labor migrants can be better used for their counties of origin becomes more and more urgent. There is an opinion that labor migration is not always negative. It is emphasized that educational migration can have a positive impact on the development of industry in the donor country, provided that the population returns home. It is noted that Ukraine often acts as a labor donor for many countries, including Poland. The main spheres of activity in which Ukrainians work abroad are given. The main benefits that donor and recipient countries receive from population migration are identified. It is emphasized that the return flows, ie the return of emigrants home from earnings abroad, change over time the ratio of benefits and losses in the donor country.
\end{abstract}

Keywords: migration processes, educational migration, consequences of migration, donor country, recipient country, migrants, cooperation 